\title{
PENGARUH MODEL PROBLEM BASED LEARNING TERHADAP KEMAMPUAN PEMECAHAN MASALAH IPA SISWA KELAS VIII SMP
}

\author{
N L.Eka Sumiantari, I Nyoman Suardana, Kompyang Selamet \\ Program Studi S1 Pendidikan IPA \\ Universitas Pendidikan Ganesha \\ Singaraja, Indonesia \\ e-mail: eka.sumiantari@undiksha.ac.id,nyoman.suardana@undiksha.ac.id, \\ kompyang.selamet@undiksha.ac.id

\begin{abstract}
Abstrak
Penelitian ini bertujuan menganalisis pengaruh model problem based learning (PBL) dengan model pembelajaran kooperatif tipe student team achievement division (STAD) terhadap kemampuan pemecahan masalah IPA siswa. Penelitian ini merupakan penelitian eksperimen semu dengan rancangan nonequivalent pretest-posttest control group design. Populasi penelitian ini adalah seluruh siswa kelas VIII SMP Negeri 7 Singaraja tahun ajaran 2017/2018 yang berjumlah 126 siswa. Sampel penelitian berjumlah 50 siswa yang diambil dengan teknik cluster random sampling sebanyak dua kelas yaitu siswa kelas VIII B sebagai kelas eksperimen diterapkan model PBL dan kelas VIII E sebagai kelas kontrol diterapkan model kooperatif tipe STAD. Objek penelitian ini adalah kemampuan pemecahan masalah IPA siswa. Data penelitian ini dikumpulkan menggunakan metode tes uraian dan dianalisis menggunakan uji ANCOVA satu jalur dengan taraf signifikansi 95\%. Hasil penelitian menunjukkan bahwa siswa yang dibelajarkan dengan model PBL memiliki kemampuan pemecahan masalah lebih baik dari model kooperatif tipe STAD. Hal tersebut ditunjukkan oleh skor rata-rata posttest kelompok yang dibelajarkan dengan model PBL yaitu sebesar 74,50 yang tergolong pada kategori cukup sedangkan kelompok yang dibelajarkan dengan model STAD yaitu sebesar 45,94 yang tergolong pada kategori sangat rendah.
\end{abstract}

Kata kunci: kemampuan pemecahan masalah, model problem based learning (PBL), model pembelajaran kooperatif tipe student team achievement division (STAD)

\footnotetext{
Abstract

This research aims at analyzing the effect of problem based learning model (PBL) with cooperative type student team achievement division model (STAD) towards the students' problem solving skills of science. This research was quasi experiment research with nonequivalent pretest-posttest control group design. The population of the research were the eighth grade students of SMP Negeri 7 Singaraja in academic year 2017/2018 which consisted of 126 students. The sample of the research were 50 students which was determined by cluster random technique which consisted of two classes, namely VIII B class as the experimental group which were taught through PBL model and VIII E class as the control group which were taught through STAD type cooperative learning model. The object of the research was the students' problem solving skills of science. The data of this research was collected by using test method and analyzed by using one-way ANCOVA test with the significant 0,05. The result of the research showed that the students which were taught through PBL model has a better science students' problem solving skills than the students who were taught through STAD type cooperative learning model. This is indicated by the average score of group posttest which is taught by PBL model that is equal to 74,50 which belong to enough category while group which is taught by STAD model that is equal to 45,94 which belong to very low category.
} 
Keywords: the students' problem solving skills of science, problem based learning model (PBL), student team achievement division type cooperative learning model (STAD)

\section{PENDAHULUAN}

Kemampuan pemecahan masalah adalah salah satu kemampuan penting yang harus dimiliki siswa karena dalam kehidupan sehari-hari setiap orang selalu dihadapkan pada berbagai masalah yang harus diselesaikan dan menuntut kreativitas agar mampu menemukan solusi dari permasalahan yang dihadapinya (Permatasari, 2014). Kemampuan pemecahan masalah melatih siswa menemukan sendiri berbagai konsep secara holistik, bermakna, otentik serta aplikatif (Hariawan, 2014). Gok dan Silay (2010) menyatakan bahwa kemampuan pemecahan masalah dipandang sangat fundamental dalam pembelajaran sains. Sains (IPA) merupakan cabang ilmu yang mempelajari tentang keteraturan alam, menguasai pengetahuan, baik fakta, konsep, prinsip, proses penemuan dan sikap ilmiah (Gunawan, Harjono dan Sutrio, 2015). Belajar IPA tidak hanya memahami konsep, namun menekankan pada pola berpikir siswa agar mampu menguasai dan memecahkan masalah secara kritis, logis, cermat dan teliti (Darwanti, 2013). Kemampuan pemecahan masalah merupakan bagian yang sangat penting dalam pembelajaran IPA, karena kegiatan memecahkan masalah menuntut siswa menemukan sendiri konsep-konsep dalam pembelajaran sehingga proses pembelajaran lebih bermakna. Mariawan (2013) juga menyatakan bahwa kemampuan pemecahan masalah merupakan aspek penting dalam pembelajaran sains, karena pemecahan masalah digunakan untuk membelajarkan siswa dalam menerapkan pengetahuan sains dan kemampuan yang diperoleh dalam pembelajaran.

Kemampuan pemecahan masalah memberikan pengalaman langsung terhadap siswa sehingga dapat menambah kemampuan siswa dalam mengontruksi, memahami dan menerapkan konsep yang telah dipelajari siswa. Berdasarkan hal tersebut, apabila dalam proses pembelajaran IPA, siswa dibiasakan mengembangkan kemampuan berpikir tingkat tinggi maka kemampuan pemecahan masalah IPA siswa menjadi lebih baik.

Kenyataan yang terjadi di lapangan, siswa masih mengalami kesulitan dalam menentukan dan memecahkan masalah yang dialaminya yang berkaitan dengan materi pembelajaran IPA. Ini dikarenakan masih banyak siswa yang hanya menghafal konsep dan kurang mampu menggunakan konsep tersebut jika menemukan masalah dalam kehidupannya yang berkaitan dengan konsep yang dimiliki, bahkan siswa kurang mampu menentukan masalah dan merumuskannya (Trianto, 2009). Selain itu, rendahnya kemampuan pemecahan masalah siswa juga dibuktikan dari rendahnya skor yang diperoleh siswa Indonesia dalam mengikuti tes TIMSS (Trends International Mathematics and Science). Berdasarkan hasil penelitian TIMSS yang mengukur tingkat pengetahuan siswa dari sekedar mengetahui fakta, konsep dan menggunakannya untuk memecahkan masalah yang sederhana hingga masalah yang memerlukan penalaran tinggi. Hasil dari penelitian TIMSS pada tahun 2011, skor yang diperoleh Indonesia adalah 406 yang merupakan skor terkecil nomor lima, sedangkan pada tahun 2015 Indonesia memperoleh skor 397 yang merupakan terkecil nomor empat dari 64 negara. Skor yang diperoleh menempatkan Indonesia pada predikat Low Science Benchmark (Martin., et al, 2015). Berdasarkan predikat yang diperoleh Indonesia pada TIMSS 2011 dan 2015 siswa Indonesia hanya memiliki beberapa pengetahuan dasar mengenai biologi, kimia, fisika dan IPA. Siswa belum mampu mendemonstrasikan dan menyampaikan pengetahuan biologi, kimia, fisika dan IPA dalam berbagai konteks. Siswa juga kurang mampu mengkomunikasikan dan menjelaskan konsep terkait dengan biologi, kimia, fisika 
dan IPA dalam kehidupan sehari-hari baik secara praktis, abstrak maupun eksperimen.

Rendahnya kemampuan pemecahan masalah siswa dalam pelajaran IPA disebabkan oleh banyak faktor. Faktor yang dapat memicu rendahnya kemampuan pemecahan masalah siswa bisa berasal dari dalam diri siswa (internal) dan bisa dari lingkungan (eksternal). Faktor internal yang dapat berpengaruh terhadap kemampuan pemecahan masalah siswa seperti, sikap, bakat, minat dan motivasi diri siswa yang masih kurang, sedangkan faktor eksternal yang dapat menyebabkan rendahnya kemampuan pemecahan masalah siswa adalah peran pendidik (guru). Peran guru yang dapat mempengaruhi kemampuan pemecahan masalah siswa adalah ketidak tepatan guru dalam memilih model pembelajaran yang digunakan pada saat proses pembelajaran di kelas. Model pembelajaran yang sering digunakan oleh guru pada saat pembelajaran adalah model pembelajaran kooperatif tipe STAD. Model pembelajaran kooperatif tipe STAD merupakan suatu model pembelajaran yang sudah menerapkan student centered (Harjono dalam Amalia, 2016). Kelemahan model pembelajaran kooperatif tipe STAD adalah membutuhkan waktu yang lebih lama untuk siswa sehingga sulit mencapai kurikulum, membutuhkan kemampuan khusus guru sehingga tidak semua guru dapat melakukan pembelajaran kooperatif, dan menuntut sifat tertentu dari siswa misalnya sifat suka bekerja sama (Budairi dalam Solihah, 2016). Ini sesuai dengan hasil penelitian yang dilakukan Chrisna dan Surya (2017) yang menyatakan bahwa model pembelajaran kooperatif tipe STAD memiliki kelemahan dalam hal meningkatkan kemampuan pemecahan masalah siswa.

Solusi untuk menindaklanjuti masalah tersebut adalah dengan menerapkan model pembelajaran yang mampu melibatkan peserta didik secara aktif dan berkontribusi dalam proses pembelajaran di kelas sehingga kemampuan pemecahan masalah IPA siswa lebih meningkat dan proses pembelajaran lebih bermakna. Salah satu model inovatif yang dapat meningkatkan kemampuan pemecahan masalah siswa adalah model problem based learning (PBL). Model PBL memiliki lima komponen, yaitu orientasi siswa pada masalah, mengorganisasikan siswa untuk belajar, membimbing menyelidiki individual atau kelompok, mengembangkan dan menyajikan hasil karya dan menganalisis dan mengevaluasi proses pemecahan masalah. Kelebihan dari model PBL adalah salah satu model yang bisa menjembatani kesenjangan antara realita keseharian siswa dengan apa yang terjadi di kelas (Delisle dalam Upayoga, 2013). Model PBL juga dapat membangkitkan minat belajar dan membangun kemampuan intelektual siswa. Hastin (dalam Astika, 2013) mengungkapkan bahwa PBL dapat meningkatkan pemahaman siswa terhadap materi yang dipelajari, kemampuan memecahkan masalah, dan keterampilan menerapkan konsep. Wheeler (dalam Astika, 2013) mengemukakan bahwa PBL dapat melatih kecakapan berpikir tingkat tinggi siswa, sehingga dengan diterapkannya model PBL daya ingat siswa terhadap pembelajaran menjadi lebih permanen karena siswa menemukan sendiri jawaban atas permasalahan yang ditemukannya.

Berdasarkan uraian tersebut, perlu dilakukan penelitian lebih lanjut tentang pengaruh model $\mathrm{PBL}$ terhadap kemampuan pemecahan msalah IPA siswa.

\section{METODE}

Penelitian ini merupakan penelitian eksperimen semu dengan rancangan nonequivalent pretest-posttest control group desaign. Populasi dalam penelitian ini adalah semua siswa kelas VIII SMP Negeri 7 Singaraja yang berjumlah 126 siswa. Sampel diambil dengan teknik cluster random sampling, diperoleh bahwa siswa kelas VIII B sebagai eksperimen yang berjumlah 25 orang dibelajarkan dengan model PBL dan siswa kelas VIII E sebagai kontrol yang berjumlah 25 orang dibelajarkan dengan model kooperatif tipe STAD.

Objek dalam penelitian ini adalah kemampuan pemecahan masalah IPA siswa. Data kemampuan pemecahan 
masalah IPA dikumpulkan menggunakan metode tes. Tes yang digunakan adalah tes uraian sebanyak sembilan butir. Tes ini digunakan untuk mengukur kemampuan pemecahan masalah IPA awal siswa (pretest) dan kemampuan pemecahan masalah IPA akhir (posttest). Karakteristik tes dalam penelitian ini adalah tes kemampuan pemecahan masalah yang, memiliki konsistensi internal butir antara 0,25 hingga 0,55 , reliabilitas sebesar 0,1956 , indeks daya beda antara 0,17 sampai 0,50 , dan indeks kesukaran antara 0,04 hingga 0,68.

Metode dan teknik analisis data yang digunakan dalam penelitian ini adalah dengan menggunakan statistik deskriptif dan statistik inferensial. Analisis statistik deskriptif digunakan untuk mendeskripsikan nilai rata-rata pretest dan posttest sedangkan analisis statistik inferensial digunakan untuk menguji hipotesis menggunakan ANCOVA satu jalur dengan taraf signifikansi 0,05 . Sebelum pengujian hipotesis, dilakukan uji asumsi meliputi uji normalitas, uji homogenitas, uji linieritas dan keberartian arah regresi serta uji homogenitas kemiringan garis regresi (uji interaksi).

\section{HASIL DAN PEMBAHASAN}

Data yang diperoleh pada penelitian ini adalah data kuantitatif, berupa skor pretest dan skor posttest kemampuan pemecahan masalah siswa. Deskripsi data ditunjukkan pada Tabel 1.

Tabel 1. Nilai Rata-Rata Pretest dan Posttest Keterampilan Proses Sains Siswa

\begin{tabular}{ccc}
\hline Kelompok & \multicolumn{2}{c}{ Nilai rata-rata } \\
\cline { 2 - 3 } & Pretest & Posttest \\
\cline { 2 - 3 } Eksperimen & 31,61 & 74,45 \\
Kontrol & 29,2 & 45,94 \\
\hline
\end{tabular}

Berdasarkan Tabel 1, dapat dideskripsikan bahwa nilai rata-rata pretest pada kelas eksperimen tidak jauh berbeda dengan kelas kontrol. Setelah diberikan perlakuan nilai rata-rata posttest di kelas eksperimen lebih lebih tinggi daripada kelas kontrol. Hal ini mengindikasikan bahwa kemampuan pemecahan masalah siswa yang dibelajarkan dengan model PBL lebih baik dari siswa yang dibelajarkan dengan model kooperatif tipe STAD.

Penelitian ini juga mendeskripsikan nilai rata-rata kemampuan pemecahan masalah pada tiap-tiap indikator kemampuan pemecahan masalah, disajikan pada Tabel 2.

Tabel 2. Deskripsi Nilai Rata-rata Kemampuan Pemecahan Masalah Siswa Masingmasing Indikator

\begin{tabular}{cccccc}
\hline No & $\begin{array}{c}\text { Indikator Kemampuan } \\
\text { Pemecahan Masalah }\end{array}$ & Rata-rata & Kualifikasi & Rata-rata & Kualifikasi \\
\hline 1 & KPM 1 & 88,33 & Baik & 76,00 & Cukup \\
2 & KPM 2 & 72,67 & Cukup & 45,33 & Sangat Kurang \\
3 & KPM 3 & 75,50 & Cukup & 38,00 & Sangat Kurang \\
4 & KPM 4 & 41,60 & Sangat Kurang & 24,00 & Sangat Kurang \\
5 & KPM 5 & 88,83 & Baik & 50,00 & Sangat Kurang \\
\hline & & \multicolumn{4}{c}{ KPM 4 : Anticipate outcomes and act }
\end{tabular}

KPM 1 : Identify problem

KPM 2 : Define goal

KPM 3 : Explore possible

KPM 5 : Look back and learn 
Berdasarkan Tabel 2, dapat dilihat bahwa nilai rata-rata setiap indikator kemampuan pemecahan masalah IPA siswa pada kelas yang dibelajarkan menggunakan model PBL lebih tinggi daripada siswa yang dibelajarkan menggunakan model pembelajaran kooperatif tipe STAD. Nilai rata-rata indikator kemampuan pemecahan masalah siswa yang paling tinggi untuk kelas eksperimen yaitu pada indikator Look back and Learn dan kelas kontrol ditunjukkan pada tahap Identify problem sedangkan nilai rata-rata indikator kemampuan pemecahan masalah siswa yang paling rendah untuk kelas eksperimen dan kelas kontrol ditunjukkan pada indikator anticipate outcomes and act.

Sebelum uji hipotesis, dilakukan beberapa uji asumsi. Hasil uji asumsi menunjukkan data telah memenuhi syarat, yaitu berdistribusi normal, memiliki varian yang homogen, memiliki hubungan yang linier antara pretest dan posttest, dan tidak terdapat interaksi antara kemampuan pemecahan masalah awal (variabel kovariat) dengan model pembelajaran.

Berdasarkan uji prasyarat yang telah dilakukan, data hasil pretest dan posttest yang telah diperoleh memenuhi semua prasyarat untuk dianalisis menggunakan uji hipotesis ANCOVA. Hipotesis yang diuji dalam penelitian ini adalah sebagai berikut.

$\mathrm{H}_{0}=$ (tidak terdapat perbedaan pengaruh model problem based learning (PBL) dengan model kooperatif student team achievement division (STAD) terhadap kemampuan pemecahan masalah IPA siswa kelas VIII SMP N 7 Singaraja).

$\mathrm{H}_{\mathrm{a}}=$ (terdapat perbedaan pengaruh model problem based learning (PBL) dengan model kooperatif student team achievement division (STAD) terhadap kemampuan pemecahan masalah IPA siswa kelas VIII SMP N 7 Singaraja).

Hipotesis nol ditolak apabila angka signifikansi yang diperoleh kurang dari 0,05. Hasil uji hipotesis ditunjukkan pada Tabel 3.

Tabel 3. Hasil Uji Hipotesis

\begin{tabular}{lccccc}
\hline \multicolumn{1}{c}{ Source } & Type III Sum of Squares & Df & Mean Square & $\boldsymbol{F}$ & Sig. \\
& & & & & \\
\hline Corrected Model & $10514.729^{a}$ & 2 & 5257.365 & 54.831 & 0.000 \\
Intercept & 11882.028 & 1 & 11882.028 & 123.922 & 0.000 \\
Pengethuan Awal & 461.109 & 1 & 461.109 & 4.809 & 0.033 \\
Model Pembelajaran & 10493.507 & 1 & 10493.507 & 109.441 & 0.000 \\
Error & 4506.491 & 47 & 95.883 & & \\
Total & 197067.000 & 50 & & & \\
Corrected Total & 15021.220 & 49 & & & \\
Corrected Model & $10514.729^{a}$ & 2 & 5257.365 & 54.831 & 0.000 \\
\hline
\end{tabular}

Berdasarkan data Tabel 3, menunjukkan bahwa variabel kelas (model pembelajaran) diperoleh nilai signifikansi lebih kecil dari 0,050, dengan demikian dapat diambil keputusan bahwa $\mathrm{H}_{0}$ ditolak $\mathrm{H}_{\mathrm{a}}$ diterima sehingga dapat ditarik kesimpulan, terdapat perbedaan kemampuan pemecahan masalah antara siswa yang dibelajarkan menggunakan model pembelajaran PBL dengan siswa yang dibelajarkan menggunakan model kooperatif tipe STAD.

\section{Pembahasan}

Berdasarkan hasil pengujian hipotesis menunjukkan bahwa kemampuan pemecahan masalah IPA siswa yang dibelajarkan dengan model PBL lebih baik dibandingkan kemampuan pemecahan masalah IPA siswa yang dibelajarkan 
menggunakan model kooperatif tipe STAD.

Berdasarkan deskripsi hasil pretest dapat dilihat bahwa nilai rata-rata pretest kelas eksperimen adalah 31,61 dan untuk kelas kontrol memiliki rata-rata 29,44 , ini artinya kemampuan pemecahan masalah awal siswa di kedua kelas adalah hampir sama. Kemampuan pemecahan masalah awal siswa dalam penelitian ini adalah sebagai kovariat, yaitu untuk mengetahui apakah kemampuan pemecahan masalah awal siswa berpengaruh terhadap kemampuan pemecahan masalah akhir siswa, dalam penelitian ini kemampuan pemecahan masalah awal siswa tidak mempengaruhi model pembelajaran di kedua kelas, karena telah dilakukan pengendalian terhadap variabel kemampuan pemecahan masalah awal siswa. Trochim (2006) menyatakan bahwa variabel kovariat adalah variabel yang digunakan untuk menghilangkan atau mengurangi noise (bias) pada analisis data yang disebabkan oleh variabel lain selain variabel yang diteliti sehingga efek dari variabel yang diteliti dapat terlihat dengan jelas. Hal ini berarti kemampuan pemecahan masalah siswa memang benar-benar dipengaruhi oleh model pembelajaran tidak dipengaruhi oleh kemampuan pemecahan masalah awal siswa. Setelah diberikan perlakuan (posttest), untuk kelas eksperimen memiliki nilai rata-rata sebesar 74,45 dan kelas kontrol memiliki rata-rata 46,94, yang artinya kemampuan pemecahan masalah siswa kelas eksperimen setelah diberikan perlakuan lebih tinggi dibandingkan kelas kontrol. Hal ini berarti model PBL lebih unggul dibandingkan dengan model pembelajaran kooperatif tipe STAD dalam meningkatkan kemampuan pemecahan masalah.

Hasil penelitian ini konsisten dengan beberapa penelitian yang telah dilakukan oleh peneliti sebelumnya, yaitu Destianingsih, et al., (2016) dan Suardani, et al., (2014). Hasil penelitiannya menunjukkan bahwa kemampuan pemecahan masalah siswa dibelajarkan dengan model PBL lebih baik dari siswa yang yang dibelajarkan dengan model pembelajaran langsung.

Kemampuan pemecahan masalah IPA siswa lebih baik pada kelas eksperimen yang dibelajarkan dengan model PBL daripada kelas kontrol yang dibelajarkan dengan model Kooperatif tipe STAD karena pada model pembelajaran PBL siswa dihadapkan pada masalah dunia nyata tanpa adanya bimbingan dari guru, siswa dituntut menemukan sendiri konsep-konsep dalam memecahkan masalah sehingga pengetahuan siswa lebih bermakna. Hal ini sesuai dengan pernyataan Duch et al., (2001) bahwa model PBL menggunakan masalah yang kompleks untuk memotivasi siswa dalam mengidentifikasi dan meneliti konsep, mereka harus memiliki pengetahuan yang cukup untuk memecahkan suatu masalah. Berbeda halnya pada model pembelajaran kooperatif tipe STAD, siswa hanya berfokus pada diskusi kelompok sehingga siswa yang memiliki kemampuan kurang dalam berdiskusi dan malu bertanya akan mengalami kesulitan saat memecahkan masalah.

Berdasarkan sintaks model PBL, pada saat menganalisis masalah, siswa didorong untuk bisa merumuskan masalah, mengidentifikasi masalah, menemukan informasi dari masalah tersebut, membuat hipotesis, dan mencoba merancang penyelesaian masalah tersebut. Hal tersebut sesuai dengan teori pembelajaran kontekstual menurut Ausubel yang memandang bahwa proses belajar benar-benar berlangsung hanya jika siswa mampu memproses atau mengontruksi sendiri informasi atau pengetahuan sedemikian rupa sehingga pengetahuan tersebut menjadi bermakna sesuai dengan kerangka berpikir mereka (Gafur, 2003).

Kegiatan melaksanakan percobaan terhadap rancangan penyelesaian yang sudah dibuat siswa. Pada kegiatan ini siswa di dalam kelompoknya sudah mendapatkan LKS, yang kemudian siswa dalam satu kelompok berdiskusi untuk merencanakan solusi pemecahan masalah dan memilih strategi yang tepat untuk memecahkan masalah tersebut. 
Siswa dituntut mahami konsep dan pendekatan yang bisa digunakan untuk memecahkan masalah. Kegiatan ini didukung oleh paradigma kontruktivistik yang menunjukkan bahwa pembelajaran harus lebih mengutamakan penyelesaian masalah, mengembangkan konsep, konstruksi solusi dan algoritma dibandingkan menghafal prosedur dan menggunakannya untuk memperoleh suatu jawaban yang benar (Suparno, 1997).

Kegiatan terakhir yang berkontribusi terhadap kemampuan pemecahan masalah siswa yaitu menyampaikan solusi yang diberikan untuk menyelesaikan masalah serta hasil dari penyelesaian masalah tersebut, pada saat ini siswa memerlukan masukan dari temantemannya terkait penyelesaian yang telah dibuat, sehingga terjadi proses diskusi untuk mendapatkan hasil yang benar. Vygotsky meyakini bahwa interaksi sosial dengan teman lain memacu terbentuknya ide baru dan memperkaya pengembangan intelektual siswa. Perkembangan intelektual terjadi pada saat individu berhadapan dengan pengalaman baru dan menantang, serta ketika mereka berusaha untuk memecahkan masalah yang muncul (Yohanes, 2010).

Dilain pihak model kooperatif tipe STAD kurang mampu meningkatkan kemampuan pemecahan masalah siswa. Hal ini dikarenakan pada saat pemberian LKS siswa langsung mengerjakan LKS secara berkelompok. Proses pembelajaran yang demikian kurang efektif karena siswa tidak diberi kesempatan untuk mengidentifikasi masalah dan menyusun solusi pemecahan masalah yang dihadapinya. Siswa mengerjakan LKS sesuai dengan panduan yang telah disediakan pada LKS. Hal ini membuat siswa malas berpikir sehingga kegiatan diskusi akan berlangsung lama karena siswa kebanyakan kurang paham mengenai rancangan solusi pada LKS maka guru harus menjelaskan kembali maksud dari LKS. Selain itu, siswa yang malas cenderung hanya memanfaatkan teman kelompok yang memiliki kemampuan lebih untuk mengerjakan LKS sehingga kontribusi seluruh siswa dalam mengerjakan LKS akan berkurang. Lubis (2017) menyatakan kekurangan dalam belajar kelompok adalah siswa yang mempunyai motivasi belajar yang rendah akan memilih tetap pasif dalam kelompoknya yang akan bepengaruh negatif terhadap kelompoknya. Selain itu, pada saat proses pembelajaran dengan model kooperatif tipe STAD tidak terdapat kegiatan yang mampu melatih siswa dalam meninjau kembali dan belajar dari pengalaman yang diperoleh sehingga siswa tidak mampu merefleksi solusi yang telah digunakan dalam memecahkan masalah. Berdasarkan hasil perbandingan tersebut model PBL mampu mengembangkan seluruh indikator kemampuan pemecahan masalah, sedangkan model kooperatif tipe STAD hanya mampu mengembangkan tiga indikator kemampuan pemecahan masalah. Hal ini berarti bahwa model PBL lebih baik dalam meningkatkan kemampuan pemecahan masalah daripada model kooperatif tipe STAD.

Model PBL dinyatakan lebih baik untuk meningkatkan kemampuan pemecahan masalah siswa dibandingkan dengan model STAD juga dilihat dari nilai rata-rata tiap-tiap indikator kemampuan pemecahan masalah yang diperoleh siswa. Secara umum nilai rata-rata kemampuan pemecahan masalah di kedua kelas setelah diberikan perlakuan mengalami penigkatan, namun peningkatan nilai rata-rata indikator kemampuan pemecahan masalah di kelas kontrol tidak terlalu tinggi dan masih berada pada kualifikasi kurang baik. Berbeda halnya pada kelas eksperimen peningkatan nilai rata-rata indikator kemampuan pemecahan masalah sudah cukup baik. Kemampuan pemecahan masalah pada kelas eksperimen lebih baik dari kelas kontrol dikarenakan diterapkannya model PBL sehingga dalam proses pembelajaran siswa menemukan sendiri konsep yang mereka gunakan dalam memecahkan masalah, pembelajaran menjadi lebih bermakna karena siswa tidak hanya sekedar 
menghafal konsep. Berbeda dengan kelas kontrol yang dibelajarkan dengan model kooperatif tipe STAD, siswa dituntut memecahkan masalah berdasarkan konsep yang sudah dibelajarkan oleh guru sehingga siswa harus menghafal konsep tersebut, jika siswa tidak ingat maka siswa tidak dapat memecahkan masalah yang dihadapinya.

Meningkatnya
kemampuan
pemecahan masalah pada kelas
eksperimen juga terlihat dari ativitas
belajar siswa. Siswa pada kelas
eksperimen cenderung lebih aktif dan memiliki motivasi belajar yang tinggi pada saat proses pembelajaran, berbeda halnya dengan siswa pada kelas kontrol siswa yang aktif dan memiliki motivasi yang baik dalam belajar hanya beberapa.

Model PBL dapat meningkatkan kemampuan pemecahan masalah siswa dengan baik, namun masih ada indikator yang berada pada kualifikasi sangat kurang yaitu pada indikator menerapkan solusi pemecahan masalah. $\mathrm{Hal}$ ini dikarenakan instrumen yang digunakan memiliki tingkat kesukaran sangat tinggi dibandingkan indikator yang lainnya. Item soal pada indikator menerapkan solusi pemecahan masalah memerlukan kemampuan matematika siswa yang baik, namun kemampuan matematika siswa masih berada pada kategori kurang. Misalnya menghitung bilangan yang besar, bilangan desimal, dan perhitungan yang kompleks. Tingginya tingkat kesukaran yang dimiliki soal dan rendahnya kemampuan matematika siswa mengakibatkan siswa kesukaran untuk memperoleh nilai rata-rata yang bagus sehingga indikator menerapkan solusi pemecahan masalah berada pada kualifikasi sangat kurang sedangkan indikator lainnya berada pada kualifikasi baik dan cukup.

Kurang maksimalnya kemampuan pemecahan masalah pada kelas eksperimen juga disebabkan beberapa kendala, yaitu (1) siswa terbiasa menunggu penjelasan guru dan tidak mau berusaha sendiri sehingga siswa masih belum terbiasa berusaha sendiri dalam mencari sumber yang berkaitan dengan materi. Siswa tidak terbiasa mencari jawaban yang mendetail serta mencoba membuktikan secara faktual melalui percobaan mengenai jawaban dari permasalah yang dihadapinya. (2) Membutuhkan waktu yang lama untuk membiasakan siswa belajar dengan model PBL. Terutama pada saat mengerjakan LKS yang harus dikerjakan secara bertahap, sesuai dengan tahapan pemecahan masalah dan sering kali siswa mengalami kendala dalam menentukan percobaan yang akan dilakukan untuk untuk menyelesaikan permasalahannya, meskipun secara matematis sebagian siswa sudah memiliki bayangan untuk menyelesaikan permasalahan yang diberikan. (3) Minat belajar yang kurang dari siswa, beberapa siswa memiliki minat belajar yang kurang bagus, hal ini terlihat dari sikapnya ketika menerima pelajaran, ia cenderung bermalas-malasan dan bermain dengan temannya yang memiliki karakter yang sama. (4) Siswa kurang aktif mencari sumber informasi. Siswa hanya mengandalkan buku pemberian sekolah saja meskipun buku tersebut satu berdua, sehingga yang tidak membawa buku tidak dapat belajar dengan maksimal. Seharusnya ada inisiatif untuk memperbanyak buku dari siswa atau mencari sumber lain supaya tidak hanya menunggu teman saja.

Kendala tersebut berusaha untuk diminimalisir dalam penelitian ini dengan beberapa cara, yaitu (1) Memberi motivasi yang lebih kepada siswa tersebut untuk belajar dan berusaha sendiri sehingga tidak menunggu namun berusaha terlebih dahulu. Setelah diberikan solusi masalah ini terjadi pada pertemuan pertama dan kedua saja, untuk pertemuan selanjutnya siswa sudah terbiasa memecahkan sendiri masalah yang dihadapinya tanpa menunggu arahan guru. (2) Membiasakan siswa dalam belajar dengan model PBL terlebih dahulu yaitu dengan memberi pengarahan yang lebih intensip sebelum melakukan percobaan/mengerjakan LKS sampai siswa terbiasa. Setelah diberikan solusi pertemuan ketiga siswa sudah terbiasa dalam mengerjakan LKS tanpa 
harus dibimbing secara intensip lagi. (3) Melakukan pendekatan terhadap siswa tersebut agar lebih fokus dalam belajar, selain itu guru harus mampu membuat pembelajaran yang lebih menarik agar siswa yang memiliki karakter seperti itu tertarik untuk belajar. Setelah diberikan solusi, masalah ini tetap berlanjut hingga pertemuan ketiga namun jumlah siswa yang memiliki minat belajar yang kurang semakin sedikit. (4) mempersilakan siswa meminjam buku di kelas lain yang tidak mendapatkan mata pelajaran yang sama. Permasalahn ini hanya terjadi pada pertemuan pertama dan untuk pertemuan selanjutnya masing-masing siswa sudah memiliki buku.

\section{SIMPULAN DAN SARAN Simpulan}

Mengacu pada rumusan masalah, analisis data dan pembahasan dapat disimpulkan beberapa hal sebagai berikut. Pertama, terdapat perbedaan kemampuan pemecahan masalah IPA siswa yang dibelajarkan dengan model PBL dengan model pembelajaran kooperatif tipe STAD, kemampuan pemecahan masalah siswa yang dibelajarkan dengan model PBL berada pada kategori cukup sedangkan kemampuan pemecahan masalah siswa yang dibelajarkan dengan model kooperatif tipe STAD berada pada kategori sangat rendah. Kedua, kemampuan pemecahan masalah paling tinggi di kelas eksperimen dan kontrol berturut-turut terletak pada indikator meninjau ulang solusi yang diperoleh dan indikator mengidentifikasi masalah.

\section{Saran}

Berdasarkan hasil penelitian di atas, dapat diajukan beberapa saran sebagai berikut. Bagi guru bidang studi IPA, model PBL sebagai alternatif pembelajaran untuk meningkatkan kemampuan pemecahan masalah IPA siswa, karena kemampuan pemecahan masalah yang baik adalah awal siswa untuk meraih prestasi belajar yang lebih tinggi.

Bagi peneliti selanjutnya disarankan untuk membuat soal indikator pemecahan masalah minimal menganalisis dan memilih materi yang cakupannya lebih luas dan bersifat terbuka tidak hanya pada perhitungan matematis sehingga siswa mampu menjawab soal dengan maksimal.

Bagi peneliti lain disarankan untuk memberikan tugas-tugas di rumah berupa fenomena, dari fenomena tersebut siswa menemukan permasalahan dan permasalahan tersebut hanya dapat dipecahkan jika siswa mau berusaha mencari sumber-sumber yang terkait. Hal ini akan memberikan motivasi bagi siswa untuk lebih giat dalam belajar.

Bagi peneliti selanjutnya yang ingin menggunakan model pembelajaran PBL hendaknya memberikan instruksi secara bertahap dan lebih mendalam agar siswa mampu mengikuti setiap tahap kegiatan pembelajaran sehingga pada pertemuan selanjutnya kegiatan pembelajaran dapat dilakukan dengan lebih cepat dan sesuai dengan alokasi waktu yang tersedia.

Bagi peneliti selanjutnya yang ingin menggunakan model pembelajaran PBL disarankan untuk menyesuaikan LKS dengan konten dan konteks materi pembelajaran. Peneliti dapat mengkombinasikan model PBL dengan pemberian games agar siswa lebih tertarik dalam mengikuti kegiatan pembelajaran

\section{DAFTAR RUJUKAN}

Amalia, R, H., Mahardika, I K., \& Gani, A, A. 2016. Pengaruh Model Pembelajaran Kooperatif Tipe Stad dengan Pendekatan SETSTerhadap Hasil Belajar Fisika Siswa SMAN 4 Jember. Jurnal Pembelajaran Fisika, 5(2): 7. Tersedia pada https : // media . neliti . com / media / publications / 138412 -ID pengaruh - model pembelajaran - kooperatif $-t$. pdf (diakses pada tanggal 8 Juli 2018)

Astika, K U., Suma, K., \& Suastra, W. 2013. Pengaruh Model Pembelajaran Berbasis Masalah Terhadap Sikap IImiah dan Keterampilan Berpikir Kritis. Jurnal Penelitian Pascasarjana 
Undiksha., 3 (1), 1-10. Tersedia pada: http:// pasca. undiksha. ac. id/e-journal/index.

php/jurnal_ipa/article/view/851

(diakses pada tanggal 10 Desember 2017).

Chrisna \& Surya. 2017. Perbedaan Kemampuan Pemecahan Masalah Matematika dengan Menggunakan Model Pembelajaran ROPES dan STAD SMP Negeri 35 Medan. Jurnal Pendidikan Matematika. Tersedia dalam: https://www.researchgate.net/pu blication/321795492 PERBEDA AN KEMAMPUAN PEMECAH AN_MASALAH_DENGAN_MO DEL_ROPES_DAN_STAD (diunduh pada tanggal 7 Januari 2018)

Darwanti, A. 2013. Upaya Peningkatan Hasil Belajar IPA dengan Creative Approach pada Siswa Kelas V SDN 03 Karangsari Jatiyoso Tahun Pelajaran 2012/2013. Skripsi Tidak dterbitkan. Surakarta: UMS. Tersedia pada http://e prints.um.s.ac.id/23060/21/NAS $\mathrm{KAH}$ _PUBLIKASI.pdf (diakses tanggal 13 Mei 2018)

Destianingsih, E., Pasaribu, A., \& Ismet. 2016. Pengaruh Model Problem Based Learning Terhadap Kemampuan Pemecahan Masalah Siswa Pada Pembelajaaran Fisika Kelas XI Di SMA Negeri 1 Tanjung Lubuk. Jurnal Inovasi Dan Pembelajaran Fisika., 3(1), 1-6. Tersedia dalam: http: //ejournal. unsri. ac. id/index. php/jipf/article/view/3423/1810 (diunduh 7 Mei 2017).

Duch, B, J., Groh, S, E., \& Allen, D, E. 2001. The power of problem based learning: A pratical "how to" for teaching undergraduate courses in any discipline. sterling: styles publishing I.C.

Gafur, A. 2003. Penerapan Konsep dan Prinsip Pembelajaran Kontekstual
(Contextual Teaching and Learning) dan Disain Pesan dalam Pengembangan Pembelajaran dan Bahan Ajar. Cakrawala Pendidikan, (3). UNY.

Gok, T \& Silay. I. 2010. The Effect of Problem Solving Strategies on Students' Achievement, Attitude and Motivation. Journal Phys. Eduction, 4(1) : 7 . Tersedia pada https : // pdfs . semantic scholar. Org. 46cb / 360952331af7fcc093ea609175c 270 cbdef0 . pdf (diakses pada tanggal 21 Juni 2018).

Gunawan, Harjono, A, \& Sutrisno. 2015. Multimedia Interaktif dalam Pembelajaran Konsep Listrik Bagi Calon Guru. Jurnal Pendidikan Fisika dan Teknologi, 1(1). Tersedia pada http://jurnalfkip.unram.ac.id/inde x.php/JPFT/article/view/230/22 (diakses pada tanggal 21 Juni 2018)

Hariawan. 2013. Pengaruh Model Pembelajaran Creative Problem Solving Terhadap Kemampuan Pemecahan Masalah Fisika pada Siswa Kelas XI SMA Negeri 4 Palu. Jurnal Pendidikan FisikaTadulako, 1(2): 48. Tersedia pada http : // jurnal. Unt ad. Ac. Id / jurnal / index. Php / EPFT / article / viewFile / 23 / 95 / 1690 (diakses pada tanggal 25 Juni 2018).

Lubis, W.A. 2017. Peningkatan Keaktifan Belajar dan Hasil Belajar Siswa dalam Pembelajaran IPA dengan Metode Kerja Kelompok Untuk Kelas III SDN Sepatan Kabupaten Tulungagung. Universitas Muhamadiyah Malang. Tersedia padahttp://eprints.umm.ac.id/356 48/ (diakses tanggal 25 Mei 2018).

Martin, M, O., Ina V.S Mullis., Pierre, F., \& Martin, H. 2015. TIMSS 2015 International Results in Science. Tersedia pada http : // 
timssandpirls . bc . edu / timss2015 / international results / wp -content / uploads / filebase / full\%20pdfs / T15 International - Results - in Science - Grade - 8 . pdf (diakses pada tanggal 1 Juli 2018).

Mariawan, I M. 2013. Karakteristik Model Pembelajaran Pemecahan Masalah Do Talk Record Dalam Sains. Jurnal Pendidikan Fisika, 3: 8. Tersedia pada http : // download . portalgaruda . org / article. php ? article = $145990 \& \mathrm{val}=1365$ (diakses pada tanggal 1 Juli 2018)

Permatasari, N Y. 201. Meningkatkan Kemampuan Siswa dalam Memecahkan masalah Matematika dengan Model Pembelajaran Treffinger. Jurnal Pendidikan Matematika, 3(1): 31. Tersedia pada https: // media. neliti. Com / media // publications / 225888 meningkatkan - kemampuan siswa - dalam - memec 3a5bf829. pdf (diakses tanggal 25 Juni 2018).

Suardani, N N., Jelantik, I B., \& Widiyanti, M. 2014. Pengaruh Model Pembelajaran Berbasis Masalah Terhadap Kemampuan Pemecahan Masalah Dan Keterampilan Proses Sains Siswa. E-Journal Program Pascasarjana Universitas Pendidikan Ganesha Program Studi IPA., 4(1), 1-9. Tersedia dalam: pasca. undiksha. ac. id/ e-journal/ index.php/ jurnal_ipa/ article/ viewFile/ 1295/997 (diunduh pada tanggal 7 Mei 2017).

Suparno, P. 1997. Filsafat konstruktivisme dalam pendidikan. Yogyakarta: KANISIUS

Soliha, A. 2016. Pengaruh Model Pembelajaran Teams Games Tournament (Tgt) Terhadap Hasil Belajar Matematika. Jurnal SAP. 1(1), 10. Tersedia pada
http://journal.Ippmunindra.ac.id/i ndex.php/SAP/article/view/1010 (diakses pada tanggal 10 Juli 2018).

TIMSS and Pirls. 2011. TIMSS and PIRLS. Tersedia pada https: //timssandpirls. bc. Edu / data release -2011 / pdf / Overview - TIMSS - and - PIRLS- 2011 Achievement . pdf diakses pada tanggal 20 Mei 2017.

Trianto. 2009. Mendesain Model Pembelajaran Inovatif-Progresif. Jakarta: Kencana Prenada Group.

Trochim, W. M. 2007. The Research Method Knowledge Base. Tersedia pada http://tro chim.hum an.cor nell. Edu /kb/ index.htm (diakses tanggal 20 Mei 2018).

Upayoga, N. T. 2014. Pengaruh Model Problem Based Learning Terhadap Kemampuan Pemecahan Masalah Fisika Siswa Kelas X SMA Negeri 1 Mengwi Tahun Pelajaran 2013/2014. Skripsi (Tidak diterbitkan). Jurusan Pendidikan Fisika, Undiksha Singaraja.

Yohanes, R, S. 2010. Teori Vygotsy dan Implementasinya dalam Pembelaaran Matematika. Widya Warta. 2, 9. Tersedia pada http : // download . portalgaruda . org / article . php ? article $=116773 \& \mathrm{val}=5324$ (diakses pada tanggal 5 Juli 2018). 